\title{
Taxonomic evidence that Vibrio carchariae Grimes et al. 1985 is a junior synonym of Vibrio harveyi (Johnson and Shunk 1936) Baumann et al. 1981
}

\author{
Karl Pedersen, ${ }^{1}$ Linda Verdonck, ${ }^{2}$ Brian Austin, ${ }^{3}$ Dawn A. Austin, ${ }^{3}$ \\ Anicet R. Blanch, ${ }^{4}$ Patrick A. D. Grimont, ${ }^{5}$ Joan Jofre, ${ }^{4}$ Stéphania Koblavi, ${ }^{5}$ \\ Jens Laurits Larsen, ${ }^{1}$ Tarja Tiainen, ${ }^{1}$ Martine Vigneulle ${ }^{6}$ and Jean Swings ${ }^{2}$
}

Author for correspondence: Karl Pedersen. Tel: +45352827 03. Fax: +4535282711.

e-mail: karl.pedersen@vetmi.kvl.dk

1 Laboratory of Fish
Diseases, Department of
Veterinary Microbiology,
Royal Veterinary and
Agricultural University,
Bülowsvej 13, DK-1870
Frederiksberg C, Denmark
2 Laboratorium voor
Microbiologie, Faculteit
Wetenschappen,
Universiteit Gent, K. L.
Ledeganckstraat 35,
B-9000 Belgium
3 Department of Biological
Sciences, Heriot-Watt
University, Riccarton,
Edinburgh EH14 4AS, UK
4 Departament de
Microbiologia, Universitat
de Barcelona, Avgda.
Diagonal 645, 08028
Barcelona, Spain
5 Centre National de Typage
Moléculaire Entérique,
Unité des Entérobactéries,
Institut Pasteur, 28 rue du
Docteur Roux, F-75724
Paris Cedex, France
6 Centre National d'Etudes
Vétérinaires et
Alimentaire, Laboratoire
de Pathologie des
Animaux Aquatiques, BP
70,29280 Plouzane, France

\section{INTRODUCTION}

Vibrio harveyi is a luminous, marine bacterium, first described by Johnson \& Shunk (1936) as 'Achromobacter harveyi'. Over the years, it has also been known under the synonyms Beneckea harveyi $(\mathrm{AL}$, Reichelt \&

Abbreviation: AFLP, amplified fragment length polymorphism.
A collection of 94 Vibrio isolates closely related to Vibrio harveyi, together with named reference and type strains, were investigated for phenotypic and genotypic properties. Using amplified fragment length polymorphism (AFLP), nine clusters were recognized. The largest cluster $(n=36)$, considered to be the bona fide $V$. harveyi group, contained the type strains of $V$. harveyi and Vibrio carchariae and most of the strains isolated from fish. The type strains of all other species, including Vibrio alginolyticus, Vibrio parahaemolyticus, Vibrio campbellii and Vibrio natriegens, clustered outside this group. By ribotyping, $V$. harveyi and $V$. carchariae patterns were very similar, insofar as they shared most bands. The $V$. campbellii type strain had several bands in common with the type strains of both $V$. harveyi and $V$. carchariae, whereas the other species were clearly distinct from these three species. DNA-DNA hybridization experiments showed $88 \%$ DNA binding between the type strains of $V$. harveyi and $V$. carchariae, whereas the DNA binding between $V$. harveyi and $V$. campbellii was $\mathbf{4 0} \%$. Although the delineation of the species $V$. harveyi is still uncertain, the authors propose, on the basis of a number of tests, to delineate a core of $V$. harveyi strains which contained the type strains of both $V$. harveyi and $V$. carchariae. It is concluded that $V$. carchariae is the junior synonym of $V$. harveyi.

Keywords: Vibrio species, AFLP, DNA-DNA hybridization, ribotyping
Baumann, 1973) and Lucibacterium harveyi (AL, Hendrie et al., 1970). The name $V$. harveyi was then given by Baumann et al. (1980) and validated in 1981 (Anonymous, 1981). V. harveyi is ubiquitous in warm marine waters and sediment, and is also a common member of the natural intestinal microflora of marine animals - vertebrates as well as invertebrates (O'Brien \& Sizemore, 1979; Ruby \& Morin, 1979). It is usually not considered to be pathogenic to fish or other vertebrates, but may cause mortalities in various 
Table 1. List of strains of $V$. harveyi- and carchariae-like strains and Vibrio type strains

\begin{tabular}{|c|c|c|c|c|c|c|}
\hline $\begin{array}{l}\text { VIB } \\
\text { no. }\end{array}$ & $\begin{array}{l}\text { Received as } \\
\text { species* }\end{array}$ & $\begin{array}{c}\text { Laboratory } \\
\text { no.*t }\end{array}$ & Synonym $\dagger$ & $\begin{array}{l}\text { Country and year } \\
\text { of isolation }\end{array}$ & Source & $\begin{array}{c}\text { AFLP } \\
\text { cluster } \ddagger\end{array}$ \\
\hline 291 & $V \cdot$ fischeri $^{T}$ & LMG $4414^{\mathrm{T}}$ & ATCC 7744, NCMB 1281 & & & UC \\
\hline 289 & V. damselae ${ }^{\mathrm{T}}$ & LMG $7892^{\mathrm{T}}$ & CDC 2588-80, ATCC 33539 & USA, 1980 & Damselfish (Chromis punctipinnis) & uc \\
\hline 305 & $V \cdot$ pelagius $^{\mathrm{T}}$ & LMG $3897^{T}$ & ATCC 25916 & Hawaii & Sea water & uc \\
\hline 853 & Vibrio sp. & D52a & & Tasmania & Atlantic salmon (Salmo salar) & uC \\
\hline 398 & $V$. harveyi & LMG 11225 & NCIMB 993 & Italy & Sea water & uC \\
\hline 392 & $V$. harveyi & HWU F373 & & Australia & Skin ulcer, barramundi & 1 \\
\hline 574 & V. harveyi? & UB A087 & & Spain, 1991 & Sea bass (Dicentrarchus labrax) & 1 \\
\hline 402 & $V$. harveyi & LMG 11661 & ATCC 33843 & USA & Sea water & 1 \\
\hline 571 & V. harveyi & UB A067 & & Spain, 1990 & Sea bass & 1 \\
\hline 413 & $V$. harveyi & IP 10.88 & & France, 1988 & Sea water & 1 \\
\hline 409 & V. harveyi & LMG 16832 & PmH 1193 St & Thailand & Black tiger prawn & 1 \\
\hline 812 & $V$. alginolyticus & UB A039 & & Spain, 1988 & Sea bass & 1 \\
\hline 572 & V. harveyi? & UB A068 & & Spain, 1990 & Sea bream (Sparus aurata) & 1 \\
\hline 295 & $V$. harveyt ${ }^{\mathrm{T}}$ & $\begin{array}{l}\text { LMG 4044 } \\
\text { (ATCC 14126) }\end{array}$ & ATCC 14126, NCMB 1280 & USA & Dead amphipod (Talorchestia sp.) & 1 \\
\hline 411 & $V$. harveyi & IP 3.86 & & South Africa, 1986 & Ulcer, fish & 1 \\
\hline 326 & $V$. alginolyticus & LMG 12091 & & Belgium & Eel (Anguilla anguilla) & 1 \\
\hline 631 & Vibrio sp. & HWU Ven.33 & & Venezuela & Bivalve mollusc & 1 \\
\hline 651 & V. harveyi/carchariae & RVAU 94-5-75 & & Denmark, 1994 & Water from aquarium with sharks in captivity & 1 \\
\hline 649 & V. harveyi/carchariae & $\mathrm{Nb} 11608$ & & Malta, 1993 & Sea bream & 1 \\
\hline 789 & Vibrio sp. & UB A030 & & Spain & Sea bream & 1 \\
\hline 351 & V. carchariae & LMG 11755 & ATCC 43516 & Bahamas & Mouth of shark & 1 \\
\hline 393 & $V$. harveyi & HWU F376 & & Australia & Heart, barramundi & 1 \\
\hline 286 & V. carchariae $^{\mathrm{T}}$ & LMG $7890^{\mathrm{T}}$ & CCUG 19116, ATCC 35084 & USA, 1982 & Brown shark (Carcharhinus plumbeus) & 1 \\
\hline 561 & V. alginolyticus & UB A038 & & Spain, 1988 & Sea bass & 1 \\
\hline 654 & V. harveyi/carchariae & RVAU 94-3-46 & & Denmark, 1994 & Water from aquarium with sharks in captivity & 1 \\
\hline 650 & V. harveyi/carchariae & $\mathrm{Nb} 11649$ & & Greece, 1993 & Sea bass & 1 \\
\hline 23 & $V$. anguillarum & HWU 58 & & Greece, 1991 & Sea bass & 1 \\
\hline 24 & V. anguillarum & HWU 59 & & Greece, 1991 & Sea bream & 1 \\
\hline 647 & V. harveyi/carchariae & $\mathrm{Nb} 11409$ & & Greece, 1992 & Sea bream & 1 \\
\hline 22 & V. anguillarum & HWU 57 & & Greece, 1991 & Sea bass & 1 \\
\hline 568 & V. harveyi? & UB A060 & & Spain, 1990 & Turbot (Scophthalmus maximus) & 1 \\
\hline 660 & V. harveyi/carchariae & $\mathrm{Nb} 11310$ & & Greece, 1990 & Sea bass & 1 \\
\hline 645 & V. harveyi/carchariae & $\mathrm{Nb} 11601$ & & Tunisia, 1993 & Sea bass & 1 \\
\hline 658 & V. harveyi/carchariae & $\mathrm{Nb} 10949$ & & France, 1990 & Sea bream & 1 \\
\hline 573 & V. harveyi? & UB A072 & & Spain, 1990 & Sea bass & 1 \\
\hline 771 & Vibrio sp. & HWU 87/0919-1 & & Tasmania & Blue tang & 1 \\
\hline 775 & Vibrio sp. & HWU $90 / 4316$ & & Tasmania & Atlantic salmon & 1 \\
\hline 643 & Vibrio sp. & HWU 0.3 & & Japan & Milkfish(Chanos chanos) & 1 \\
\hline 652 & V. harveyi/carchariae & $943 / 93$ & & Italy, 1993 & Sea bass & 1 \\
\hline 570 & V. harveyi & UB A065 & & Spain, 1990 & Sea bream & 1 \\
\hline 633 & Vibrio sp. & HWU Ven. 40 & & Venezuela & Bivalve mollusc & 1 \\
\hline 648 & V. harveyi/carchariae & RVAU 93-5-157 & & Denmark, 1993 & Liver from shark dead in captivity & UC \\
\hline 788 & Vibrio sp. & UB A029 & & Spain & Sea bream & 2 \\
\hline 618 & Vibrio sp. & HWU Ven. 3 & & Venezuela & Penaeid shrimp & 2 \\
\hline 816 & Vibrio sp. & HWU Ven. 45 & & Venezuela & Sediment & 2 \\
\hline 811 & V. alginolyticus & UB A017 & & Spain, 1986 & Sea bass & 2 \\
\hline 646 & V. harveyi/carchariae & RVAU 93-8-287 & & Denmark, 1993 & Water from aquarium with sharks in captivity & 2 \\
\hline 296 & $V$. mediterrane $\mathrm{i}^{\mathrm{T}}$ & LMG $11258^{\mathrm{T}}$ & ATCC 43341 & Spain & Coastal sediment & uc \\
\hline 641 & Vibrio sp. Zoea & HWU 85Z1 & & Japan & & 3 \\
\hline 642 & Vibrio sp. Zoea & HWU $87 Z 1$ & & Japan & & 3 \\
\hline 622 & Vibrio sp. & HWU Ven.16 & & Venezuela & Penaeid shrimp & 3 \\
\hline 397 & V. harveyi & LMG 10948 & $\begin{array}{l}\text { NCIMB 1896, ATCC } 29919 \text {, } \\
\text { Baumann } 74\end{array}$ & Hawaii & Sea water & 3 \\
\hline 667 & Vibrio sp. & $94-5-74$ & & Denmark, 1994 & Water from aquarium with sharks in captivity & 3 \\
\hline 788 & Vibrio sp. & UB A029 & & Spain & Sea bream & 3 \\
\hline 400 & V. harveyi & LMG 11659 & CCUG 16178, Baumann 130 & Hawaii & Sea water & 3 \\
\hline 396 & V. harveyi & LMG 10947 & NCIMB 1847 & Red Sea & Sea water & 3 \\
\hline 819 & V. vulnificus & V. vulnificus 6.80 & & Senegal, 1980 & Fish & 4 \\
\hline 822 & V. vulnificus & V. vulnificus 8.80 & & Senegal, 1980 & Shrimp & 4 \\
\hline 629 & Vibrio sp. & HWU Ven.29 & & Venezuela & Bivalve mollusc & 4 \\
\hline 404 & V. harveyi & LMG 16835 & PmH 2193 SK & Thailand & Black tiger prawn & 4 \\
\hline 403 & V. harveyi & LMG 16828 & PmH 293 SK & Thailand & Black tiger prawn & 4 \\
\hline 406 & V. harveyi & LMG 16830 & PmH 593 STC & Thailand & Black tiger prawn & 4 \\
\hline 395 & V. harveyi & LMG 10946 & NCIMB 394 & India? & Prawn & 4 \\
\hline 391 & V. harveyi & LMG 13949 & & Thailand, 1990 & Shrimp & 4 \\
\hline 538 & V. vulnificus & & AAHRI 06 & Thailand, 1992 & Shrimp & 4 \\
\hline 347 & V. campbellii & LMG 11256 & ATCC 25921 & Hawaii & Sea water & 5 \\
\hline 285 & V. campbellit ${ }^{T}$ & LMG $11216^{\mathrm{T}}$ & ATCC 25920 & Hawaii, 1971 & Sea water & 5 \\
\hline 696 & $V$. harveyi & LMG (80M8) & & Spain, 1989 & Oyster & 5 \\
\hline 697 & $V$. harveyi & LMG (90M4) & & Spain, 1989 & Oyster & 5 \\
\hline 348 & V. campbellii & LMG 11257 & ATCC 33864 & Hawaii & Sea water & 5 \\
\hline 401 & $V$. harveyi & LMG 11660 & ATCC 33842 & USA & Sea water & UC \\
\hline
\end{tabular}


Table 1. (cont.)

\begin{tabular}{|c|c|c|c|c|c|c|}
\hline $\begin{array}{l}\text { VIB } \\
\text { no. }\end{array}$ & $\begin{array}{c}\text { Received as } \\
\text { species }^{\star}\end{array}$ & $\begin{array}{c}\text { Laboratory } \\
\text { no. }{ }^{\star}+\end{array}$ & Synonym $\dagger$ & $\begin{array}{c}\text { Country and year } \\
\text { of isolation }\end{array}$ & Source & $\underset{\text { cluster }}{\text { AFLP }}$ \\
\hline 585 & $V$. parahaemolyticus & UB A084 & & Spain & Sea bream & 6 \\
\hline 584 & $V$. nereis? & UB A108 & & Spain, 1993 & Turbot & 6 \\
\hline 657 & $V$, harveyi/carchariae & $\mathrm{Nb} 10732$ & & France, 1990 & Sea bass & $\mathrm{UC}$ \\
\hline 394 & V. harveyi & HWU F377 & & Australia & Heart, barramundi & 7 \\
\hline 628 & Vibrio sp. & HWU Ven.28 & & Venezuela & Penaeid shrimp & 7 \\
\hline 655 & V, harveyi/carchariae & $\mathrm{Nb} 10324$ & & France, 1989 & Sea bass & 7 \\
\hline 214 & V. anguillarum & LMG 13241 & & Greece, 1991 & Sea water & 7 \\
\hline 661 & V. harveyi/carchariae & $\mathrm{Nb} 11421$ & & Tunisia, 1992 & Sea bass & 7 \\
\hline 656 & V. harveyi/carchariae & $\mathrm{Nb} 11406$ & & Greece, 1990 & Sea bass & 7 \\
\hline 569 & $V$. harveyi? & UB A063 & & Spain, 1990 & Turbot & 7 \\
\hline 304 & V. parahaemolyticus ${ }^{T}$ & LMG $2850^{\mathrm{T}}$ & ATCC 17802 & Japan, 1965 & Patient with food poisoning & 8 \\
\hline 803 & V. vulnificus & LMG 16874 & AAHRI 010 & Thailand, 1992 & Shrimp & 8 \\
\hline 306 & $V$, proteolyticus ${ }^{\mathrm{T}}$ & LMG $7893^{\mathrm{T}}$ & ATCC 15338 & USA, 1958 & Intestine of isopod (Imnoria tripunctata) & UC \\
\hline 283 & V. alginolyticus ${ }^{\mathrm{T}}$ & LMG $4408^{\mathrm{T}}$ & ATCC 17749 , NCMB 1903 & Japan & Spoiled horse macharel (Trachuris trachuris) & 9 \\
\hline 350 & V. carchariae & LMG 11754 & ATCC 43515 & Bahamas & Mouth of shark & 9 \\
\hline 666 & Vibrio sp. & $93-12-344 / 1$ & & Denmark, 1993 & Water from aquarium with sharks in captivity & 9 \\
\hline 299 & $V$. natriegens $^{\mathrm{T}}$ & LMG $10935^{\mathrm{T}}$ & ATCC 14048 & USA & Salt marsh mud & uC \\
\hline 293 & V. furnissii $^{\mathrm{T}}$ & LMG $7910^{T}$ & ATCC 35016 & Japan & Human faeces & UC \\
\hline 310 & V. vulnificus ${ }^{\mathbf{T}}$ & LMG $13545^{\mathrm{T}}$ & ATCC 27562 & USA & Human blood & UC \\
\hline 301 & $V . n e r e i s$ & LMG $3895^{\mathrm{T}}$ & ATCC 25917 & Hawaii & Sea water & $\mathrm{UC}$ \\
\hline 308 & V. splendidus ${ }^{T}$ & LMG $4042^{\mathrm{T}}$ & ATCC 33125 & & & UC \\
\hline 290 & V. diazotrophicus ${ }^{\mathrm{T}}$ & LMG $7893^{\mathrm{T}}$ & ATCC 33466 & Canada, 1981 & Sea urchin (Strongylocentrocus dreobrachiensis) & UC \\
\hline 292 & V. fluvialis $^{\mathrm{T}}$ & LMG $7894^{\mathrm{T}}$ & ATCC 33809 & Bangladesh & Human faeces & UC \\
\hline
\end{tabular}

* T, Type strain.

† LMG, Laboratorium voor Microbiologie, Rijksuniversiteit Gent, Belgium; HWU, Heriot-Watt University, Edinburgh, UK; UB, Universitat de Barcelona, Spain; IP, Institut Pasteur, Paris, France; ATCC, American Type Culture Collection, Rockville, MD, USA; RVAU, Royal Veterinary and Agricultural University, Copenhagen, Denmark; CDC, Centers for Disease Control and Prevention, Atlanta, USA; NCIMB, National Collection of Industrial and Marine Bacteria, Aberdeen, UK; NCMB, National Collection of Marine Bacteria, Aberdeen, UK; CCUG, Culture Collection, University of Gothenburg, Göteborg, Sweden.

$\ddagger$ UC, Unclustered.

shellfish species (Karunasagar et al., 1994; LavillaPitogo et al., 1990; Liu et al., 1996; Pass et al., 1987).

The first reports of Vibrio carchariae as a pathogen were published in 1984, after the organism had been isolated in 1982 from a brown shark (Carcharhinus plumbeus) found dead in captivity (Grimes et al., 1984a, b). The biochemical properties were thoroughly described by Grimes et al. (1984a, b), who also showed that the organism was pathogenic to various elasmobranch fish and to mouse cell cultures. The name of the species was approved in 1985 (Anonymous, 1985). Grimes et al. (1985) described the bacterial flora of sharks caught off the Bahamas coast, and mainly found Vibrio alginolyticus, $V$. harveyi, Vibrio furnissii, Vibrio damselae, $V$. carchariae and some unidentified vibrios. This was the first report of the isolation of $V$. carchariae in nature, i.e. not associated with disease in sharks.

$V$. harveyi and $V$. carchariae were shown to be members of the normal flora of carcharinid sharks (Grimes et al., 1993). Recently, we have studied bacterial strains isolated from outbreaks of disease among sea bass (Dicentrarchus labrax) and sea bream (Sparus aurata) in aquaculture, and from sharks held in captivity, as well as from water samples from the tanks in which they were kept. These bacteria were identified as $V$. harveyi or $V$. carchariae, but we were not able to distinguish the two species. In a study of Grimes et al. (1993), $V$. harveyi and $V$. carchariae clustered together on the basis of biochemical characters, and Alsina \& Blanch (1994) could not separate the two species by biochemical properties. In addition, the type cultures of these two species showed almost identical 16S rRNA base sequences (Aznar et al., 1994; Kita-Tsukamoto et al., 1993; Ruimy et al., 1994). These results leave no doubt that $V$. harveyi and $V$. carchariae are closely related. The purpose of the present study was to identify and characterize $V$. harveyi- and $V$. carchariae-like organisms and to compare type strains of the two species to evaluate more precisely the relationship between them by means of phenotypic and genotypic properties.

\section{METHODS}

Bacterial strains. A total of 94 Vibrio strains were examined, including cultures tentatively identified as Vibrio harveyi or $V i b$ rio carchariae, together with the type strains of $V$. harveyi, $V$. carchariae, Vibrio alginolyticus, Vibrio campbellii, Vibrio damselae, Vibrio diazotrophicus, Vibrio fischeri, Vibrio fluvialis, Vibrio furnissii, Vibrio mediterranei, Vibrio natriegens, Vibrio nereis, Vibrio parahaemolyticus, Vibrio pelagius, Vibrio proteolyticus, Vibrio splendidus and Vibrio vulnificus (Table 1). The species names in Table 1 are the names received or which had been previously assigned on the basis of biochemical tests. All strains were maintained in $20-25 \%(\mathrm{v} / \mathrm{v})$ glycerol at $-70,-80$ or $-140^{\circ} \mathrm{C}$. Active cultures were maintained as bench cultures at room temperature on marine agar (Difco), on marine agar supplemented with $5 \%(\mathrm{w} / \mathrm{v})$ sterile calf blood, or on Tryptone Soya Agar (Oxoid) with $1 \%$ (w/v) $\mathrm{NaCl}$. 


\section{Amplified fragment length polymorphism (AFLP) fingerprinting of genomes}

Extraction of genomic DNA. Cells were harvested from marine agar and washed in $500 \mu \mathrm{l} \mathrm{RS}$ buffer $(150 \mathrm{mM} \mathrm{NaCl}, 10 \mathrm{mM}$ EDTA; pH 8.0). After centrifugation, the cells were resuspended in $100 \mu \mathrm{l}$ TE buffer $(10 \mathrm{mM}$ Tris $/ \mathrm{HCl}, 1 \mathrm{mM}$ EDTA; $\mathrm{pH} \mathrm{7.6)}$ and $15 \mu \mathrm{l}$ RNase $\left(250 \mu \mathrm{g} \mathrm{ml}^{-1}\right)$ was added to the suspensions. Lysis of the cells using Sarkosyl/ guanidinium thiocyanate (Sigma) and further extraction of genomic DNA were as described by Pitcher et al. (1989). The DNA was finally dissolved in $100 \mu \mathrm{TE}$ buffer $(10 \mathrm{mM}$ Tris, $0.1 \mathrm{mM}$ EDTA; pH 8.0). The DNA concentration was determined by measuring the $A_{260}$ on a spectrophotometer $\left(1 A_{260}\right.$ unit $\left.=50 \mu \mathrm{g} \mathrm{DNA} \mathrm{ml}{ }^{-1}\right)$. The integrity of the DNA was checked by electrophoresis in a submerged horizontal agarose gel $(0 \cdot 8-1 \cdot 0 \%, \mathrm{w} / \mathrm{v})$ using an electrophoresis buffer (40 mM Tris-acetate, $1 \mathrm{mM}$ EDTA; pH 8.0) containing $0.5 \mu \mathrm{g}$ ethidium bromide $\mathrm{ml}^{-1}$. DNA preparations were stored at $-20^{\circ} \mathrm{C}$.

Oligonucleotide adaptors and primers. The sequences of the HindIII and TaqI adaptors and primers used in this study are given in detail by Janssen et al. (1996).

Template preparation. Template preparation was as described by Vos et al. (1995) and Janssen et al. (1996). Thus in this study, $1 \mu \mathrm{g}$ DNA was digested with 10 units $H$ indIII and TaqI in a final volume of $30 \mu \mathrm{l}$. HindIII and TaqI adaptors were added to a final concentration of 0.04 and $0.4 \mu \mathrm{M}$, respectively, and ligated to the restriction fragments. The DNA was subsequently precipitated with $1.25 \mathrm{M}$ ammonium acetate and $50 \%(\mathrm{v} / \mathrm{v})$ 2-propanol. Template DNAs were stored at $-20^{\circ} \mathrm{C}$.

AFLP reactions. AFLP reactions employed two oligonucleotide primers, one corresponding to the HindIII ends and one corresponding to the TaqI ends. The HindIII primer was radioactively end-labelled using $\left[\gamma^{33} \mathrm{P}\right] \mathrm{ATP}$ and T4 polynucleotide kinase (Vos et al., 1995). Selective amplification and PCR reactions were performed on a PE 9600 thermocycler (Perkin Elmer) and as described by Janssen et al. (1996).

Gel analysis. Prior to gel loading and electrophoresis, mixtures were heated for $3 \mathrm{~min}$ at $95^{\circ} \mathrm{C}$ and then rapidly cooled on ice to prevent nucleic acid secondary structures from reannealing. Each sample $(1 \cdot 8-2 \cdot 0 \mu \mathrm{l})$ was loaded on a $5 \%$ denaturing sequencing polyacrylamide gel (obtained as premixed SequaGel solutions from National Diagnostics). To $100 \mathrm{ml}$ casting solution, $0.8 \mathrm{ml} 10 \%$ ammonium persulfate and $40 \mu \mathrm{l} \quad N, N, N^{\prime}, N^{\prime}$-tetramethylethylenediamine were added, and gels were cast using a SequiGen $38 \times 50 \mathrm{~cm}$ gel apparatus (Bio-Rad). TBE (100 mM Tris, $100 \mathrm{mM}$ boric acid, $2 \mathrm{mM}$ EDTA; pH 8.3) was used as electrophoresis buffer. Gels were run at a constant power of $110 \mathrm{~W}$ for approximately $150 \mathrm{~min}$. After electrophoresis, gels were transferred to $3 \mathrm{MM}$ Whatman chromatography paper and vacuum-dried on a gel dryer (model 583; Bio-Rad) for $50 \mathrm{~min}$ at $80^{\circ} \mathrm{C}$. A sheet of Hyperfilm MP (Amersham) was exposed to the dried gel. Exposure times varied between 19 and $24 \mathrm{~h}$, depending on the measured radioactivity of the gel. Films were developed using a Fuji RGII X-ray Film Processor. Autoradiograms were scanned by a RayVen RSU1 densitoscanner (X-Ray Scanner). Digitized optical densities were saved as TIFF files and further processed using the GelCompar 3.1 software (Applied Maths, Kortrijk, Belgium). Digital images were normalized and combined according to the methods described by Vauterin \& Vauterin (1992). A similarity matrix was created using the
Dice coefficient, $S_{\mathrm{AB}}$ (Sneath \& Sokal, 1973). For band comparison, a band position tolerance value of $0.8 \%$ was allowed to compensate for misalignment of homologous bands due to technical imperfections. The unweighted pair group method using average linkages was used to cluster the patterns (Priest \& Austin, 1993; Sneath \& Sokal, 1973; Vauterin \& Vauterin, 1992). Each strain was tested only once.

DNA-DNA hybridization. DNA for DNA-DNA hybridization was extracted and purified as described by Marmur (1961). The levels of DNA binding were determined spectrophotometrically from the initial renaturation rates as described by De Ley et al. (1970). The experiments were carried out in $2 \times \mathrm{SSC}$ (SSC is $0.15 \mathrm{M} \mathrm{NaCl}, 0.015 \mathrm{M}$ sodium citrate) at $70.9{ }^{\circ} \mathrm{C}$, a temperature calculated from the $\mathrm{G}+\mathrm{C}$ mol $\%$ as described by De Ley (1970). Each figure is the mean of triplicate experiments.

Ribotyping. Ribotyping was performed following the method described previously (Austin et al., 1995). DNA was extracted from overnight cultures in tryptic casein soy broth supplemented with $2 \%(\mathrm{w} / \mathrm{v}) \mathrm{NaCl}$, using the AutoGen automate. DNA (2-5 mg) was digested with $M l u \mathbf{I}$ (Boehringer Mannheim). Restriction fragments were separated by electrophoresis in $0.8 \%$ agarose gels (Appligene) in TBE (89 mM Tris, $89 \mathrm{mM}$ boric acid, 2 mM EDTA; pH 8.3) buffer and subsequently transferred (VacuGene System; Pharmacia-LKB) and fixed $\left(80^{\circ} \mathrm{C}\right.$ for $\left.15 \mathrm{~min}\right)$ to nylon membranes (Hybond-N; Amersham International). Hybridization with an acetylaminofluorene-labelled rRNA probe (Eugentec) and subsequent immunoenzymic revelation of hybridized fragments by the application of mouse antiacetylaminofluorene monoclonal antibodies followed by phosphatase-conjugated anti-mouse antibody, and using nitro blue tetrazolium (Sigma) and 5-bromo-4-chloro-3indolyl phosphate (Sigma) as substrates, was performed as described by Grimont et al. (1989) and Austin et al. (1995). Alternatively, the method described by Pedersen \& Larsen (1993) was used. The type cultures were tested several times in various combinations, always with identical results, apart from a few cases of incomplete digestion, whereas other strains tested were run only once.

Plasmid profiling and restriction analysis of plasmids. Bacteria were propagated overnight at $20^{\circ} \mathrm{C}$ in LuriaBertani broth (Gibco) or veal infusion broth (Difco) supplemented with $0.5 \%(\mathrm{w} / \mathrm{v}) \mathrm{NaCl}$. Plasmid DNA was extracted by the method of Kado \& Liu (1981), separated by gel electrophoresis in 0.6-1.0\% agarose gels (SeaKem GTG; FMC BioProducts) in TAE buffer, pH 8.0 (40 mM Tris, $5 \mathrm{mM}$ sodium acetate, $1 \mathrm{mM}$ EDTA), stained with ethidium bromide $\left(2 \mathrm{mg} \mathrm{ml}^{-1}\right)$ and photographed under UV light. Restriction analysis was carried out as described by Pedersen et al. (1996a). Briefly, plasmid DNA was extracted by the method of Olsen (1990) and digested with HindIII, BamHI or EcoRI according to the manufacturer's instructions (Promega). Fragments were separated on $1.0 \%$ agarose gels and stained with ethidium bromide or SYBR Green DNA Gel Stain I (FMC BioProducts). HindIII-digested lambda DNA was used as molecular mass markers. All plasmid experiments were run at least in triplicate.

\section{RESULTS}

\section{AFLP genomic fingerprinting}

After numerical analysis of the AFLP banding patterns of the strains, using $S_{\mathrm{AB}}$, nine clusters were delineated 
at $50 \%$ (Fig. 1). At this level, the Vibrio type strains belonged to separate clusters, except $V$. harvey $i$ and $V$. carchariae, which clustered together.

The type strains of $V$. fischeri, $V$. damselae, $V$. pelagius, $V$. mediterranei, $V$. proteolyticus, $V$. natriegens, $V$. furnissii, $V$. vulnificus, $V$. nereis, $V$. splendidus, $V$. diazotrophicus and $V$. fluvialis each constituted single strain groups.

Cluster $1(n=36)$ contained both the type strains of $V$. harveyi (VIB 295 ) and $V$. carchariae (VIB $286^{\mathrm{T}}$ ). This cluster was considered to contain the bona fide $V$. harveyi strains. However, only $52 \%(24 / 46)$ of the strains that were received as $V$. harveyi or $V$. carchariae clustered with these type strains. The other strains received as $V$. harveyi or $V$. carchariae grouped in clusters 2, 3, 4 and 7, or together with the type strains of $V$. campbellii (cluster 5) or $V$. alginolyticus (cluster 9). Strains in cluster 1 were isolated worldwide and originated from fish (teleost and elasmobranch fish) $(n=27)$, shellfish $(n=4)$ and environmental sources $(n=5)$. Cluster 1 also contained misidentified $V$. alginolyticus and Vibrio anguillarum strains and strains received as unidentified Vibrio sp.

Cluster $2(n=5)$, containing strains from South America and Europe, originated from fish, shellfish and environmental sources. These strains were received as $V$. harveyi/V. carchariae, $V$. alginolyticus or Vibrio sp.

Cluster $3(n=8)$ contained three strains received as $V$. harveyi, two as Vibrio sp. Zoea and three as Vibrio sp. One strain was from sea bass, whereas remaining strains were from environmental sources $(n=4)$, shrimp $(n=1)$ or unknown $(n=2)$. The strains came from South America, Hawaii, Asia and Europe.

The strains in cluster 4 originated from shellfish $(n=$ 8 ) and fish $(n=1)$. They had been isolated in South America, Asia and Africa. Three of the strains in this cluster were originally identified as $V$. vulnificus. However, the type strains of $V$. vulnificus clustered separately from these three strains and had a clearly different AFLP banding pattern.

Cluster $5(n=5)$ contained the $V$. campbellii type strain (VIB $285^{\mathrm{T}}$ ) and two other $V$. campbellii strains from Hawaii, together with two $V$. harveyi-like strains originating from oysters in Spain, whereas cluster 6 included only two Spanish fish isolates, previously identified as $V$. parahaemolyticus and $V$. nereis.

Strains in cluster $7(n=7)$ came from Australia, South America and the Mediterranean Sea, and included isolates previously identified as $V$. harveyi, $V$. carchariae or $V$. anguillarum. Strains in this cluster originated from fish, shellfish and water.

Clusters $8(n=2)$ and $9(n=3)$ contained the type strain of $V$. parahaemolyticus and $V$. alginolyticus, respectively, together with strains received as $V$. vulnificus, $V$. carchariae and Vibrio sp. The isolates came from different parts of the world.

Unnamed Vibrio strains were scattered over clusters 1, 2, 3, 4, 7 and 9 .

\section{DNA-DNA hybridization}

By DNA-DNA hybridization, the DNA binding between the $V$. harveyi and $V$. carchariae type strains was calculated to be $88 \%$, whereas the DNA binding between the $V$. harveyi and $V$. campbellii type strains was $40 \%$.

\section{Ribotyping}

The ribotypes of the $V$. harveyi and $V$. carchariae type strains were almost identical, sharing most of the bands (Fig. 2). A second strain received as $V$. carchariae, VIB 351, had a ribotype pattern that was very similar but not quite identical to those of these type cultures. Also, the type strain of $V$. campbellii shared a number of bands with those of $V$. harveyi and $V$. carchariae. In contrast, the ribotype patterns of the other closely related species, $V$. parahaemolyticus, $V$. alginolyticus, $V$. proteolyticus and $V$. natriegens, were clearly distinct from the pattern of $V$. harveyi and $V$. carchariae. The ribotype patterns of the tested strains belonging to AFLP cluster 1 showed some diversity. The unclustered strain VIB 648, between AFLP clusters 1 and 2 , had a ribotype pattern that was indistinguishable from that of VIB 660 from AFLP cluster 1 and, likewise, the ribotype pattern of strain VIB 646 from AFLP cluster 2 was almost identical to that of VIB 651 from AFLP cluster 1.

\section{Plasmids}

In general, profiles were heterogeneous, with plasmid sizes ranging from 3.0 to approximately $150 \mathrm{~kb}$. However, some plasmids showed considerable homology, as judged from the restriction analysis using three different restriction enzymes, BamHI, HindIII and $E c o$ RI. Some $V$. harveyi strains isolated from the Mediterranean area carried a plasmid varying in size from 70 to approximately $95 \mathrm{~kb}$. This plasmid was detected in 16 strains belonging to the bona fide $V$. harveyi AFLP cluster 1. Plasmids of similar size were found outside this cluster, but these plasmids were all unrelated to the $70-95 \mathrm{~kb}$ plasmid found in AFLP cluster 1 , as judged from their restriction patterns. Likewise, six of these strains of the AFLP cluster 1 additionally carried a plasmid of $40-50 \mathrm{~kb}$ with a high degree of homology, as judged from their restriction patterns, whereas plasmids of similar size in other strains both in and outside AFLP cluster 1 were unrelated to this plasmid. Finally, the $135 \mathrm{~kb}$ plasmid of strain 651 (AFLP cluster 1), the $150 \mathrm{~kb}$ plasmid of strain VIB 648 (unclustered strain between AFLP clusters 1 and 2) and the $130 \mathrm{~kb}$ plasmid of VIB 646 


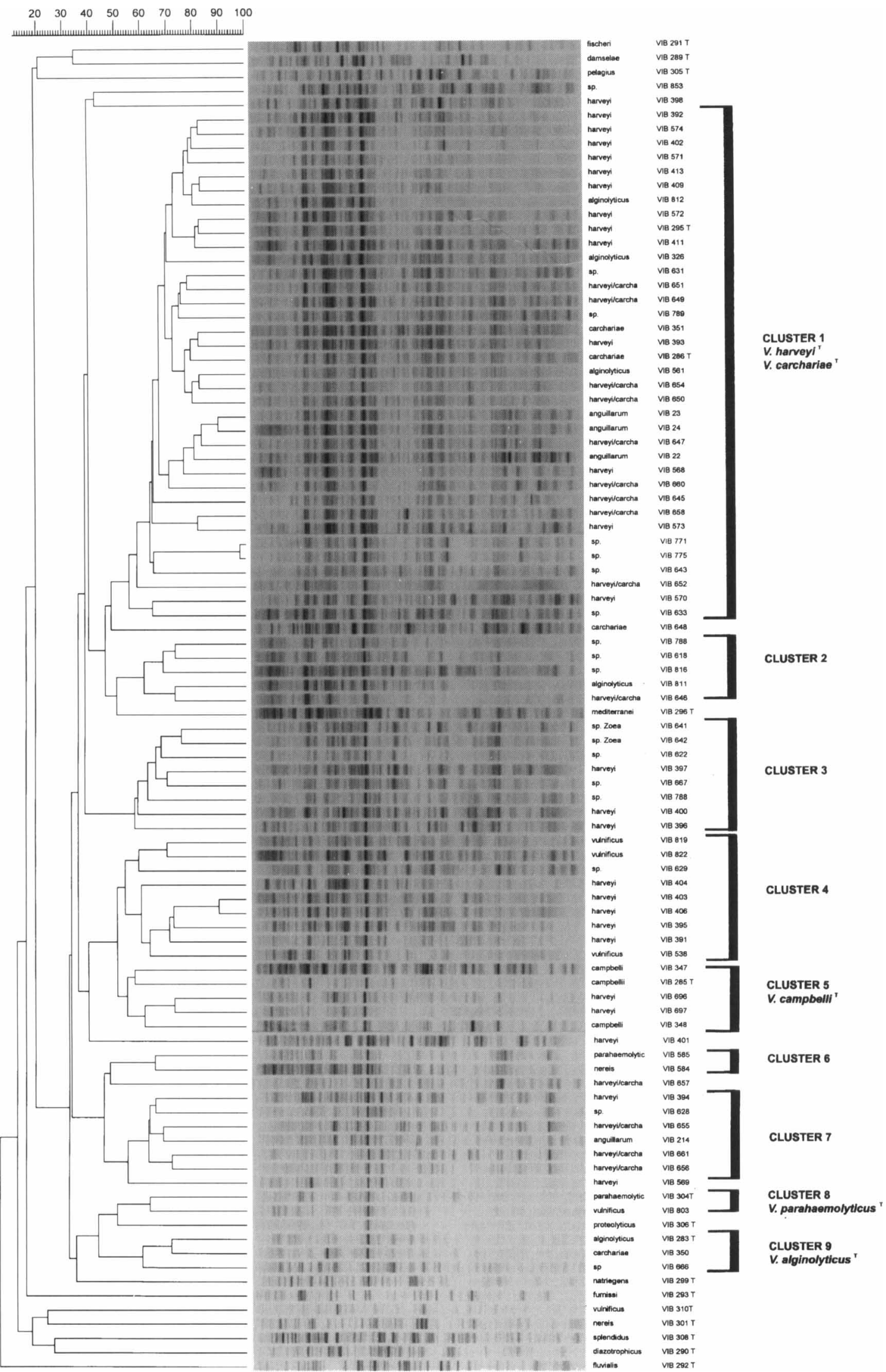

Fig. 1. AFLP patterns and the derived dendrogram of $V$. harveyi strains, related organisms and Vibrio type strains. 


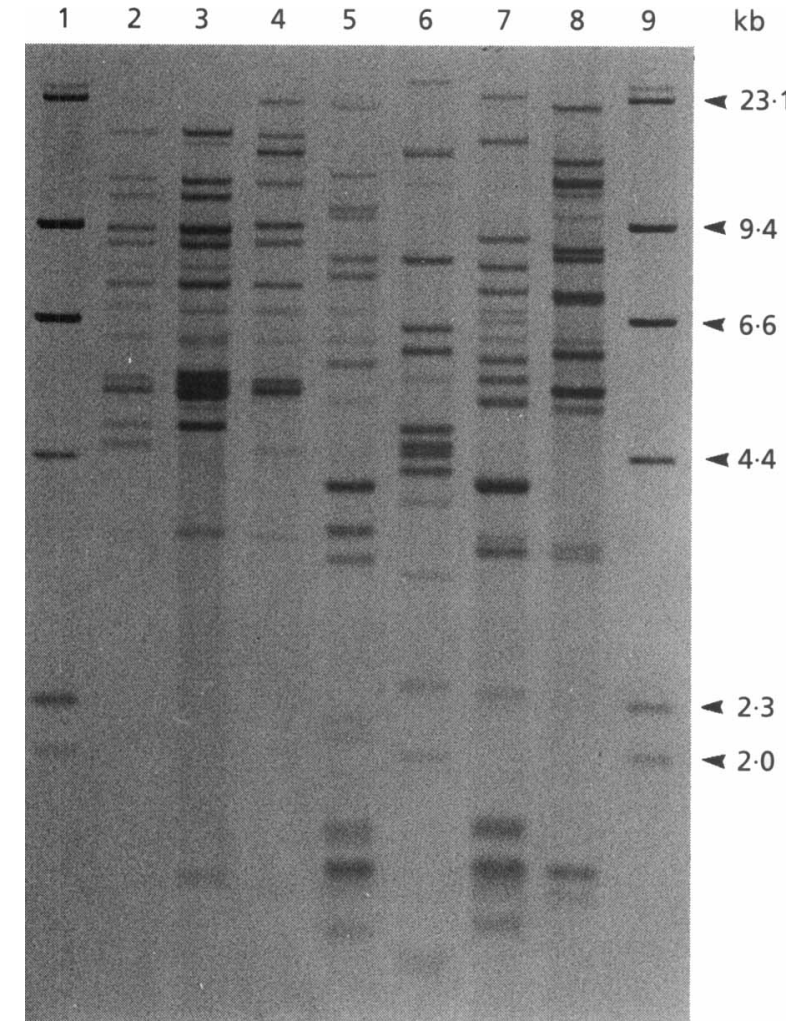

Fig. 2. Ribotype patterns of the type strains of $V$. harveyi (lane $2)$. $V$. carchariae (lane 3), V. campbellii (lane 4), $V$. parahaemolyticus (lane 5), $V$. proteolyticus (lane 6), $V$. alginolyticus (lane 7) and $V$. natriegens (lane 8 ). Lanes 1 and 9 , HindIII-digested $\lambda$ DNA as molecular mass markers.

(AFLP cluster 2) had similar, although not identical, restriction patterns.

\section{DISCUSSION}

This study has sought to re-examine the phenotypic and genotypic heterogeneity within, and relationship between, $V$. harveyi and $V$. carchariae. For this purpose, bacterial isolates were collected from a range of geographical locations, hosts and environmental sources, and subjected to investigation.

\section{AFLP}

AFLP is a reliable and reproducible genomic fingerprinting technique that has been applied in recent taxonomic studies (Huys et al., 1996; Janssen et al., 1996; Verdonck et al., 1995). In these studies, numerical analyses of the AFLP banding patterns not only confirmed the genomic groups in Xanthomonas, Aeromonas and Vibrio which were formed on the basis of DNA-DNA hybridization and/or ribotyping, but also allowed the differentiation of individual strains of a species. In the present study, AFLP fingerprinting was used successfully to differentiate between strains in the collection. Strains that were biochemically characterized as $V$. harveyi or $V$. carchariae showed a marked genotypic heterogeneity. Some of the isolates were reidentified on the basis of their AFLP banding patterns as $V$. alginolyticus, $V$. parahaemolyticus or $V$. campbellii. The type strains of $V$. harveyi and $V$. carchariae were both found in AFLP cluster 1. This observation indicates that these two species cannot be distinguished genotypically and consequently are subjective synonyms. The AFLP banding patterns of the type strains of $V$. mediterranei, $V$. campbellii, $V$. alginolyticus, $V$. proteolyticus, $V$. natriegens and $V$. parahaemolyticus were more similar to the $V$. harveyi group than those of the other type strains included. In the AFLP dendrogram, $V$. mediterranei and $V$. campbellii had the highest similarity with the $V$. harveyi cluster. The type strain of $V$. mediterranei was positioned as an unclustered single strain between clusters 2 and 3 , whereas the $V$. campbellii type strain was found in cluster 5 together with other $V$. campbellii strains. Thus cluster 1 is considered to be $V$. harveyi sensu stricto, cluster $5 \mathrm{~V}$. campbellii, cluster $8 \mathrm{~V}$. parahaemolyticus and cluster $9 V$. alginolyticus, whereas the taxonomic position of clusters $2,3,4,6$ and 7 , which did not contain any type strains, at present remains unclear.

\section{DNA-DNA hybridization}

The results obtained by AFLP were supported by the DNA-DNA hybridization studies. The DNA-DNA hybridization results in the present study showed $88 \%$ DNA binding between the $V$. harvey $i$ and $V$. carchariae type strains, indicating that these two strains should be considered to belong to the same species. The homology between the $V$. harveyi and $V$. campbellii type strains was considerably lower, $40 \%$. Reichelt et al. (1976) found a close relationship between $V$. harveyi and $V$. campbellii $(65 \%)$ and $V$. alginolyticus and $V$. parahaemolyticus $(65 \%)$. The relationship between these two groups was approximately $55 \%$, and the relationship of the two groups to $V$. natriegens was approximately 50 and $40 \%$, respectively. $V$. vulnificus was more distant: the genetic relationship of $V$. vulnificus to these five species was $30-35 \%$. These DNA-DNA homologies perfectly reflect the AFLP dendrogram (Fig. 1) in the present study. Pujalte et al. (1992) found $0 \%$ relative DNA binding of $V$. mediterranei to $V$. campbellii using the $\mathrm{S} 1$ nuclease method, 0 and $14 \%$ relative binding to $V$. carchariae using the $\mathrm{S} 1$ nuclease and the hydroxyapatite methods, respectively, and $15 \%$ relative binding to $V$. harveyi using the hydroxyapatite method. These three species therefore seem to have the same level of genetic distance from $V$. mediterranei. In a very recent report by Ishimaru \& Muroga (1997), the DNA-DNA homology between $V$. harveyi and $V$. carchariae was found to be $87-93 \%$, whereas the DNA homology of 
these species to $V$. campbellii was $45-50 \%$. These results are very close to those of the present study. The Vibrio sp. Zoea, described as the cause of mortality of the zoeal state of swimming crab (Portunus trituberculatus), showed $46-51 \%$ homology to $V$. harveyi, $V$. carchariae and $V$. campbellii but was concluded to belong to a new species (Ishimaru \& Muroga, 1997). In the present study, the two Vibrio sp. Zoea strains $86 \mathrm{Z}-1$ and $87 \mathrm{Z}-1$ both belonged to the AFLP cluster 3 with uncertain taxonomic position.

\section{Ribotyping}

The ribotyping data supported the AFLP and DNA-DNA hybridization results. The $V$. harveyi and $V$. carchariae type strains shared most bands and did not deviate more from each other than other strains tested from AFLP cluster 1. The type strain of $V$. campbellii shared some bands with the $V$. harveyi and $V$. carchariae type strains, whereas the patterns of the closely related species $V$. alginolyticus, $V$. parahaemolyticus and $V$. natriegens were clearly distinct from this pattern (Fig. 2). Also, the pattern of the $V$. mediterranei type strain deviated very clearly from that of $V$. harveyi and $V$. carchariae.

Other authors have compared rRNA sequences of different Vibrio species. Kita-Tsukamoto et al. (1993) found the partial 16S rRNA sequences of $V$. harveyi and $V$. carchariae to be more than $99 \%$ identical, and the type strains of $V$. harveyi and $V$. carchariae, $V$. parahaemolyticus, $V$. alginolyticus and $V$. campbellii all had sequences that were very closely related. Aznar $e t$ al. (1994), Dorsch et al. (1992), Ruimy et al. (1994) and Wiik et al. (1995) found a high degree of homology of $16 \mathrm{~S}$ rRNA sequences of $V$. harveyi, $V$. parahaemolyticus, $V$. alginolyticus, $V$. campbellii, $V$. natriegens and $V$. proteolyticus, thus forming the core of the genus Vibrio together with $V$. vulnificus (Dorsch et al., 1992). The highest homology was found between $V$. harveyi and $V$. alginolyticus ( $99.17 \%$ ) (Aznar et al., 1994) and between $V$. alginolyticus and $V$. campbellii $(99 \cdot 9 \%)$ (Wiik et al., 1995). These sequence similarities almost correspond to that found between $V$. anguillarum serogroups $\mathrm{O} 1$ and $\mathrm{O} 2$ (Wiik et al., 1995). V. harveyi and $V$. carchariae were not included in these studies. In their study of small-subunit rRNA sequences, Ruimy et al. (1994) found a $0.77 \%$ dissimilarity (genetic distance) between $V$. harveyi and $V$. carchariae, $0.93 \%$ between $V$. carchariae and $V$. campbellii, but only $0.54 \%$ between $V$. harveyi and $V$. campbellii. This seemed to indicate that $V$. harveyi is genetically more closely related to $V$. campbellii than to $V$. carchariae (Ruimy et al., 1994).

$V$. carchariae and $V$. harveyi are frequently isolated together from sharks or from the environment (Grimes et al., 1985, 1993), and numerical taxonomy based on biochemical characters has shown that they cluster together with a high similarity. However, in the literature, a set of characters by which they can be distinguished has never been published. In a study by
Grimes et al. (1993), $21 V$. harveyi and three $V$. carchariae strains clustered together. However, these authors were able to distinguish between the two species at a high level of similarity and it was indicated that there may be differences between them on the basis of their utilization of certain compounds as sole carbon sources. Alsina \& Blanch (1994) also recorded that $V$. harveyi and $V$. carchariae were different in their utilization of melibiose and arabinose as sole carbon sources. Urease production is mentioned as an important trait for virulence of both $V$. carchariae and $V$. damselae but some $V$. harveyi isolates have also been described as urease-positive (Bryant et al., 1986a, b; Grimes et al., 1985, 1993).

On the basis of well-chosen characters, Ortigosa et al. (1989) found two groups within $V$. harveyi - one group clustering close to $V$. alginolyticus and $V$. parahaemolyticus and a second clearly distinct from these. This second group mainly differed by being positive for luminescence, arbutin and alginate, negative for ornithine decarboxylase and sucrose, and variable for lactose and urease. Unfortunately, the $V$. carchariae type strain was not included in the study.

The close phenotypic relationship between $V$. harveyi, $V$. carchariae, $V$. alginolyticus, $V$. parahaemolyticus and $V$. proteolyticus was also found by Baumann et al. (1984), Bryant et al. (1986a, b) and West et al. (1986). These authors concluded that biochemical criteria are not always sufficient to distinguish between these species because they have too many variable characters. In a very comprehensive study by Bryant $e t$ al. (1986a, b), the type strains of $V$. harveyi, V. campbellii, $V$. alginolyticus and $V$. parahaemolyticus grouped close together, $V$. harveyi and $V$. campbellii forming a close group and $V$. alginolyticus and $V$. parahaemolyticus another. Unfortunately, $V$. harveyi or $V$. carchariae strains were not included in any of these studies.

One strain received as $V$. carchariae (VIB 350) was reidentified as $V$. alginolyticus. This strain clearly clustered together with the other $V$. harveyi and $V$. carchariae strains in the original description of this isolate (Grimes et al., 1993). We therefore doubt the authenticity of our subculture of VIB 350 .

\section{Plasmids}

Some of the $V$. harveyi isolates contained one or two plasmids, approximately $40-50$ and $70-80 \mathrm{~kb}$, respectively, showing homology by restriction analysis. These isolates all fell into the AFLP cluster 1. They were all isolated from diseased fish (sea bass, sea bream or turbot). Additionally, they were all isolated from the Mediterranean area. Such plasmids that, within a species or a sub-group of a species, display homology have also been detected in other Vibrio species, e.g. $V$. vulnificus (Biosca et al., 1997), Vibrio ordalii (Pedersen et al., 1996a) and $V$. anguillarum (additional to the pJM1 plasmid) (Pedersen et al., 1996b). However, other strains also carried plasmids. In general, there 
was considerable diversity in the size of these plasmids. Only a single report on the presence of plasmids in $V$. harvey $i$ has appeared so far: McCall \& Sizemore (1979) found that some strains carried a plasmid of $38 \mathrm{MDa}$ that encoded a bacteriocin. Whether this plasmid was related to the ones described in the present study is unknown. An important observation was that three other strains, VIB 651, VIB 648 and VIB 646, shared a plasmid with some homology. These three strains all came from the same aquarium, but while two of the strains were from water samples, the third was isolated in pure culture from the liver of a dead shark, and thus had caused septicaemia in the shark. VIB 651 belonged to AFLP cluster 1, VIB 646 to AFLP cluster 2, and the third, VIB 648, was the unclustered strain between clusters 1 and 2. Additionally, these three strains had almost identical ribotype patterns. These results strongly indicate that AFLP clusters 1 and 2 and the unclustered VIB 648 should be considered to be $V$. harveyi.

\section{ACKNOWLEDGEMENTS}

This study was supported by the EU, contract no. AIRCT92-0341. Colleagues are thanked for the gift of strains. The assistance of Ms Sylvie van Eygen, Ms Cindy Snauwaert, Ms Annette Rasmussen, Ms Betina Nielsen and Ms Farah Bahrani is gratefully acknowledged.

\section{REFERENCES}

Alsina, M. \& Blanch, A. R. (1994). A set of keys for biochemical identification of environmental Vibrio species. $J$ Appl Bacteriol 76, 79-85.

Anonymous (1981). Validation of the publication of new names and new combinations previously effectively published outside the IJSB. List no. 6. Int J Syst Bacteriol 31, 215-218.

Anonymous (1985). Validation of the publication of new names and new combinations previously effectively published outside the IJSB. List no. 17. Int J Syst Bacteriol 35, 223-224.

Austin, B., Alsina, M., Austin, D. A. \& 10 other authors (1995). Identification and typing of Vibrio anguillarum: a comparison of different methods. Syst Appl Microbiol 18, 285-302.

Aznar, R., Ludwig, W., Amann, R. I. \& Schleifer, K. H. (1994). Sequence determination of rRNA genes of pathogenic Vibrio species and whole-cell identification of Vibrio vulnificus with rRNA-targeted oligonucleotide probes. Int J Syst Bacteriol 44, 330-337.

Baumann, P., Baumann, L., Bang, S. S. \& Woolkalis, M. J. (1980). Re-evaluation of the taxonomy of Vibrio, Beneckea, and Photobacterium: abolition of the genus Beneckea. Curr Microbiol 4, 127-132.

Baumann, P., Furniss, A. L. \& Lee, J. V. (1984). Genus I. Vibrio Pacini 1854, 411 AL. In Bergey's Manual of Systematic Bacteriology, vol. 1, pp. 518-538. Edited by N. R. Krieg \& J. G. Holt. Baltimore: Williams \& Wilkins.

Biosca, E., Amaro, C., Larsen, J. L. \& Pedersen, K. (1997). Phenotypic and genotypic characterization of Vibrio vulnificus: proposal for the substitution of the subspecific taxon biotype for serovar. Appl Environ Microbiol 63, 1460-1466.

Bryant, T. N., Lee, J. V., West, P. A. \& Colwell, R. R. (1986a). Numerical classification of species of Vibrio and related genera. $J$ Appl Bacteriol 61, 437-467.
Bryant, T. N., Lee, J. V., West, P. A. \& Colwell, R. R. (1986 b). A probability matrix for the identification of species of Vibrio and related genera. J Appl Bacteriol 61, 469-480.

De Ley, J. (1970). Reexamination of the association between melting point, buoyant density, and chemical composition of deoxyribonucleic acid. $J$ Bacteriol 101, 738-754.

De Ley, J., Cattoir, H. \& Reynaerts, A. (1970). The qualitative measurement of DNA hybridization from renaturation rates. Eur J Biochem 12, 133-142.

Dorsch, M., Lane, D. \& Stackebrandt, E. (1992). Towards a phylogeny of the genus Vibrio based on 16S rRNA sequences. Int J Syst Bacteriol 42, 58-63.

Grimes, D. J., Colwell, R. R., Stemmler, J., Hada, H., Maneval, D., Hetrick, F. M., May, E. B., Jones, R. T. \& Stoskopf, M. (1984a). Vibrio species as agents of elasmobranch disease. Helgol Meeresunters 37, 309-315.

Grimes, D. J., Stemmler, J., Hada, H., May, E. B., Maneval, D., Hetrick, F. M., Jones, R. T., Stoskopf, M. \& Colwell, R. R. (1984b). Vibrio species associated with mortality of sharks held in captivity. Microb Ecol 10, 271-282.

Grimes, D. J., Brayton, P., Colwell, R. R. \& Gruber, S. H. (1985). Vibrios as autochthonous flora of neritic sharks. Syst Appl Microbiol 6, 221-226.

Grimes, D. J., Jacobs, D., Swartz, D. G., Brayton, P. R. \& Colwell, R. R. (1993). Numerical taxonomy of Gram-negative, oxidasepositive rods from carcharinid sharks. Int $J$ Syst Bacteriol 43, 88-98.

Grimont, F., Chevrier, D., Grimont, P. A. D., Lefevre, M. \& Guesdon, J. L. (1989). Acetylaminofluorene-labeled ribosomal RNA for use in molecular epidemiology and taxonomy. Res Microbiol 140, 447-454.

Hendrie, M. S., Hodgkiss, W. \& Shewan, J. M. (1970). The identification, taxonomy, and classification of luminous bacteria. J Gen Microbiol 64, 151-169.

Huys, G., Coopman, R., Janssen, P. \& Kersters, K. (1996). Highresolution genotypic analysis of the genus Aeromonas by AFLP fingerprinting. Int $J$ Syst Bacteriol 46, 572-580.

Ishimaru, K. \& Muroga, K. (1997). Taxonomical reexamination of two pathogenic Vibrio species isolated from milkfish and swimming crab. Fish Pathol 32, 59-64.

Janssen, P., Coopman, R., Huys, G., Swings, J., Bleeker, M., Vos, P., Zabeau, M. \& Kersters, K. (1996). Evaluation of the DNA fingerprinting method AFLP as a new tool in bacterial taxonomy. Microbiology 142, 1881-1893.

Johnson, F. H. \& Shunk, I. V. (1936). An interesting new species of luminous bacteria. J Bacteriol 31, 585-592.

Kado, C. T. \& Liu, S.-T. (1981). Rapid procedure for detection and isolation of large and small plasmids. $J$ Bacteriol 145, 13651373.

Karunasagar, I., Pai, R., Malathi, G. R. \& Karunasagar, I. (1994). Mass mortality of Penaeus monodon larvae due to antibioticresistant Vibrio harveyi infection. Aquaculture 128, 203-209.

Kita-Tsukamoto, K., Oyaizu, H., Nanba, K. \& Simidu, U. (1993). Phylogenetic relationships of marine bacteria, mainly members of the family Vibrionaceae, determined on the basis of $16 \mathrm{~S}$ rRNA sequences. Int J Syst Bacteriol 43, 8-19.

Lavilla-Pitogo, C. R., Baticados, M. C. L., Cruz-Lacierda, E. R. \& de la Pena, L. D. (1990). Occurrence of luminous bacterial diseases of Penaeus monodon larvae in the Philippines. Aquaculture 91 , $1-13$.

Liu, P.-C., Lee, K.-K., Yii, K.-C., Kou, G.-H. \& Chen, S.-N. (1996). 
Isolation of Vibrio harveyi from diseased Kuruma prawns Penaeus japonicus. Curr Microbiol 33, 129-132.

McCall, J. O. \& Sizemore, R. K. (1979). Description of a bacteriocinogenic plasmid in Beneckea harveyi. Appl Environ Microbiol 38, 974-979.

Marmur, J. (1961). A procedure for the isolation of deoxyribonucleic acid from microorganisms. $J$ Mol Biol 3, 208-218.

O'Brien, O. \& Sizemore, R. K. (1979). Distribution of the luminous bacterium Beneckea harveyi in the semitropical estuarine environment. Appl Environ Microbiol 38, 928-933.

Olsen, J. E. (1990). Improved method for rapid isolation of plasmid DNA from wild-type Gram-negative bacteria for plasmid restriction profile analysis. Lett Appl Microbiol 10, 209-212.

Ortigosa, M., Esteve, C. \& Pujalte, M.-J. (1989). Vibrio species in seawater and mussels: abundance and numerical taxonomy. Syst Appl Microbiol 12, 316-325.

Pass, D. A., Dybdahl, R. \& Mannion, M. M. (1987). Investigations into the causes of mortality of the pearl oyster, Pinctada maxima (Jamson), in Western Australia. Aquaculture 65, 149-169.

Pedersen, K. \& Larsen, J. L. (1993). rRNA gene restriction patterns of Vibrio anguillarum serogroup O1. Dis Aquat Org 16, 121-126.

Pedersen, K., Koblavi, S., Tiainen, T. \& Grimont, P. A. D. (1996 a). Restriction fragment length polymorphism of the pMJ101-like plasmid and ribotyping of the fish pathogen Vibrio ordalii. Epidemiol Infect 117, 385-391.

Pedersen, K., Tiainen, T. \& Larsen, J. L. (1996 b). Plasmid profiles, restriction fragment length polymorphisms and O-serotypes among Vibrio anguillarum isolates. Epidemiol Infect 117, 471-478.

Pitcher, D. G., Saunders, N. A. \& Owen, R. J. (1989). Rapid extraction of bacterial genomic DNA with guanidium thiocyanate. Lett Appl Microbiol 8, 151-156.

Priest, F. \& Austin, B. (1993). Modern Bacterial Taxonomy, 2nd edn. London: Chapman \& Hall.
Pujalte, M. J., Ortiz-Conde, B. A., Steven, S. E., Esteve, C., Garay, E. \& Colwell, R. R. (1992). Numerical taxonomy and nucleic acid studies of Vibrio mediterranei. Syst Appl Microbiol 15, 82-91.

Reichelt, J. L. \& Baumann, P. (1973). Taxonomy of the marine, luminous bacteria. Arch Microbiol 94, 283-330.

Reichelt, J. L., Baumann, P. \& Baumann, L. (1976). Study of genetic relationships among marine species of the genera Beneckea and Photobacterium. Arch Microbiol 110, 101-120.

Ruby, E. G. \& Morin, J. G. (1979). Luminous enteric bacteria of the marine fishes: a study of their distribution, densities, and dispersion. Appl Environ Microbiol 38, 406-411.

Ruimy, R., Breittmayer, V., Elbaze, P., Lafay, B., Boussemart, O., Gauthier, M. \& Christen, R. (1994). Phylogenetic analysis and assessment of the genera Vibrio, Photobacterium, Aeromonas, and Plesiomonas deduced from small-subunit rRNA sequences. Int $J$ Syst Bacteriol 44, 416-426.

Sneath, P. H. A. \& Sokal, R. R. (1973). Numerical Taxonomy: The Principles and Practice of Numerical Classification. San Francisco: W. H. Freeman.

Vauterin, L. \& Vauterin, P. (1992). Computer-aided objective comparison of electrophoresis patterns for grouping and identification of microorganisms. Eur Microbiol 1, 37-41.

Verdonck, L., Van Eygen, S., De Bruyne, C., Janssen, P. \& Swings, J. (1995). The use of AFLP for the genomic fingerprinting of Vibrio anguillarum strains. In Abstracts of the 7th International Conference of the European Association of Fish Pathologists, Mallorca, Spain, p. 195.

Vos, P., Hogers, R., Bleeker, M. \& 8 other authors (1995). AFLP: a new technique for DNA fingerprinting. Nucleic Acids Res 23, 4407-4414.

West, P. A., Brayton, P. R., Bryant, T. N. \& Colwell, R. R. (1986). Numerical taxonomy of species of Vibrio isolated from aquatic environments. Int J Syst Bacteriol 36, 531-543.

Wiik, R., Stackebrandt, E., Valle, O., Daa, F. L., Rodseth, O. M. \& Andersen, K. (1995). Classification of fish-pathogenic vibrios based on comparative 16S rRNA analysis. Int $J$ Syst Bacteriol 45, 421-428. 